Schulich School of Law, Dalhousie University

Schulich Law Scholars

Articles, Book Chapters, \& Popular Press

Faculty Scholarship

2022

\title{
Animal Rights Activism and the Constitution: Are Ag-Gag Laws Justifiable Limits?
}

Jodi Lazare

Dalhousie University Schulich School of Law, jodi.lazare@dal.ca

Follow this and additional works at: https://digitalcommons.schulichlaw.dal.ca/scholarly_works

Part of the Animal Law Commons, and the Constitutional Law Commons

\section{Recommended Citation}

Jodi Lazare, "Animal Rights Activism and the Constitution: Are Ag-Gag Laws Justifiable Limits?" Osgoode Hall LJ [forthcoming in 2022].

This Article is brought to you for free and open access by the Faculty Scholarship at Schulich Law Scholars. It has been accepted for inclusion in Articles, Book Chapters, \& Popular Press by an authorized administrator of Schulich Law Scholars. For more information, please contact hannah.steeves@dal.ca. 
FORTHCOMING IN THE OSGOODE HALL LAW JOURNAL (2022)

Animal Rights Activism and the Constitution: Are Ag-Gag Laws Justifiable Limits?

By Jodi Lazare*

\section{Introduction}

It is a troubling time to be an animal rights activist in Canada. In 2019, Alberta amended its trespass legislation to create harsh penalties, including potential imprisonment, for trespassing onto private property, and for obtaining permission to enter private property based on false pretences. ${ }^{1}$ In 2020, the province prohibited obstruction of, or interference with, public infrastructure, including highways and agricultural operations. ${ }^{2}$ In Ontario, since 2020, it is likewise an offence to enter a place where animals are kept, without prior authorization; there, too, entry based on false pretences is considered trespassing. ${ }^{3}$ Further, as in Alberta and, more recently, Manitoba, ${ }^{4}$ it is an offence in Ontario to "stop, hinder, obstruct or otherwise interfere with a motor vehicle transporting farm animals"5 and to "interfere or interact with a farm animal being transported by a motor vehicle without the prior consent of the driver of the motor vehicle." ${ }^{\prime}$ In effect, the trespass legislation, seemingly introduced in response to a number of instances where

\footnotetext{
${ }^{*}$ DCL, McGill University; Assistant Professor, Schulich School of Law, Dalhousie University. This work was first presented at the Emerging Scholars Workshop in Law, Animals \& Society hosted by the Animals \& Society Research Initiative at the University of Victoria and supported by the Brooks Institute for Animal Rights \& Policy. I am deeply indebted to Maneesha Deckha for organizing the workshop, inviting me to be a part of it, and providing invaluable feedback on the paper, as well as Doug Kysar, Justin Marceau, and Delciana Winders for their thoughtful and detailed comments. I am also grateful to Jan Dutkiewicz and Troy Vettese for the opportunity to present this work at the Weatherhead Center for International Affairs and the Animal Law and Policy Program at Harvard Law School. The conversation that followed undoubtedly enriched this work. I am thankful for the excellent research and editorial assistance of Hartwell Millett, Ella Murphy, Kinnar Power, and Kelsey Warr and for comments on earlier drafts from Sarah Berger-Richardson, Elaine Brooks-Craig, Maureen Duffy, Angela Lee, Liam McHugh-Russell, and Katie Sykes. Finally, the comments of two anonymous reviewers and the editorial team at the Osgoode Hall Law Journal certainly enhanced the quality of this work, which was supported by an Insight Development Grant from the Social Sciences and Humanities Research Council of Canada.

${ }^{1}$ Bill 27, Trespass Statues (Protecting Law-Abiding Property Owners) Amendment Act, 1st Sess, 30th Leg, Alberta, 2019 (assented to 5 December 2019), SA 2019, c 23 [Bill 27].

${ }^{2}$ See Critical Infrastructure Defence Act, SA 2020, c C-32.7 [CIDA].

${ }^{3}$ See Security from Trespass and Protecting Food Safety Act, 2020, S.O. 2020, c. 9 [Security from Trespass Act].

${ }^{4}$ Bill 62, The Animal Diseases Amendment Act, 3d Sess, 42nd Leg, Manitoba 2020 (assented to 20 May 2021), SM 2021, c 53 [Bill 62].

${ }^{5}$ Security from Trespass Act, supra note 3, s 6(1).

${ }^{6} \mathrm{Ibid}, \mathrm{s} 6(2)$.
} 
animal rights activists occupied spaces on industrial animal farms and similar animal exploitation businesses, ${ }^{7}$ makes it illegal to gain entry onto and to conduct undercover investigations of the animal use industry. ${ }^{8}$ Where the provisions related to transport are concerned, the legislation effectively prohibits demonstrations on public roads, a regular activity of members of the "vegan anti-speciest and animal-centric organisation" called the Animal Save Movement, ${ }^{9}$ who protest outside of slaughterhouses in an effort to "bear witness" to animal suffering and to spread awareness of the violence of industrial animal farming. ${ }^{10}$

The laws in both Alberta and Ontario are said to be grounded in the general objective of protecting the food supply. Specifically, the statutes purport to respond to concerns about risks to the safety of farmers and their families from those that trespass onto their properties, risks to the safety of animal transporters when protestors interfere with moving vehicles, and risks to animals themselves, in terms of their safety and biosecurity. The aim of the legislation will be further examined below, but for present purposes, the stated legislative objective illustrates its parallel with American laws known as "ag-gag," or agricultural gag laws, which, in their most recent iteration, involve the "creative use of trespass laws to suppress information about public harms." 11 American ag-gag legislation, aimed at limiting whistleblowing in the animal agriculture industry, has taken many forms, such as anti-trespass laws, anti-defamation laws, and prohibitions on recording and disseminating footage from industrial farms. ${ }^{12}$ But all have had the same effect:

\footnotetext{
7 See Jodi Lazare, "Ag-Gag Laws, Animal Rights Activism, and the Constitution: What is Protected Speech?" (2020) 58:1 Alta L Rev 83 at 84 (detailing a number of occupations and/or undercover investigations in Canada between 2014 and 2020).

${ }^{8}$ Note that while the legislation may have been spurred by animal activism on private property, in Alberta, it is not limited in application to the agriculture industry.

${ }^{9}$ Animal Save Movement, “About Us", online: <https://thesavemovement.org/about/>.

${ }^{10}$ See Maneesha Deckha, "The Save Movement and Farmed Animal Suffering: The Advocacy Benefits of Bearing Witness as a Template for Law” (2019) 5 Can J Comparative \& Contemporary L 77; Anita Krajnc, "Bearing Witness: Is Giving Thirsty Pigs Water Criminal Mischief or a Duty" (2017) 23:2 Animal L 479.

11 Justin F Marceau, “Ag Gag Past, Present, and Future” (2015) 38:4 Seattle U L Rev 1317 at 1319.

12 See ibid.
} 
"they limit speech critical of the agricultural industry."13 Importantly, a number of American statutes, all of which contained prohibitions on entering an agricultural site based on a misrepresentation, have been invalidated as unconstitutional limits on the First Amendment right to free speech. ${ }^{14}$ As I suggest below, while the analysis differs, the same general reasoning underlies the evaluation of the Canadian statutes' validity under the Canadian Charter of Rights and Freedoms. ${ }^{15}$

In an earlier article, I suggested that Canadian ag-gag laws constitute a limit to the Charter right to freedom of expression. ${ }^{16}$ In this article, I make the case that the legislation is not a justifiable limit and is therefore of no force or effect, pursuant to section 52 of the Constitution Act, $1982 .{ }^{17}$ In other words, I sketch out the analytical approach by subjecting the legislation to the test established in $R v$ Oakes for determining whether rights-infringing legislation may be justified in the interests of the collective. ${ }^{18}$ Specifically, my analysis focuses on the laws in force in Alberta and Ontario, the first two jurisdictions to adopt ag-gag legislation. However, the reasoning around section 1 should readily apply to parallel statutory developments such as Manitoba's law as it relates to transport, and any future legislation that might employ similar means to achieve the same objectives. ${ }^{19}$

\footnotetext{
13 Ibid.

${ }^{14}$ Animal Legal Def Fund v Wasden, 878 F 3d 1184 (9th Cir 2018) [Wasden]; Animal Legal Def Fund v Herbert, 263 F Supp (3d) 1193, 1198 (D Utah 2017) [Herbert]; Animal Legal Def Fund v Reynolds, 353 F Supp (3d) 812 (SD Iowa 9 Jan 2019) [Reynolds].

${ }^{15}$ Canadian Charter of Rights and Freedoms, s 1, Part I of the Constitution Act, 1982, being Schedule B to the Canada Act 1982 (UK), 1982, c 11 [Charter].

${ }^{16}$ See Lazare, supra note 7.

${ }_{17}$ Constitution Act, 1982, s 52(1), being Schedule B to the Canada Act 1982 (UK), 1982, c 11. 18 [1986] 1 SCR 103, 26 DLR (4th) 200 [Oakes].

${ }^{19}$ See e.g. Daphné Cameron, “Antispécisme: un groupe de travail pour empêcher d'autres infractions” (22 January 2020) online: La Presse <https://www.lapresse.ca/actualites/202001/22/01-5257866-antispecisme-un-groupe-detravail-pour-empecher-dautres-infractions.php?fbclid=IwAR1S_zNbuKwD111aItBuEm2-PQwoD14FcUxL5Y6qppB6vIxMC6RDNpM96k\%3E> (on the creation of a Quebec governmental task force to study how other Canadian provinces are dealing with on-farm trespassers).
} 
Part 1 first explains the legislative background and summarizes my earlier argument that the activities targeted by ag-gag legislation are a form of high-value, constitutionally protected speech. Next, in keeping with the section 1 framework, Part 2 examines the contextual factors that influence the rigour with which a court might approach the Oakes test. Part 3 then queries whether the legislation has a pressing and substantial objective and suggests that while the government may struggle to meet its burden, the legislation would, nevertheless, likely pass this step. Part 4 argues that the legislation is not rationally connected to the legislative objective. Part 5 shows that the provisions are not minimally impairing. Last, Part 6 suggests that the legislation is not proportionate in its negative and positive impacts, independent of legislative purpose.

This article is primarily doctrinal in nature. It draws on legislation, case law, Hansard, and relevant scholarship on constitutional rights interpretation. It is also partly comparative, drawing as it does on the body of American scholarship on ag-gag legislation and the First Amendment and looking to the American case law striking down similar laws. As with my earlier work on Canadian ag-gag legislation, this article fills a gap in Canadian legal scholarship on the constitutional dimensions of animal rights activism as well as the legality of limits on the activities of activists. It should accordingly contribute to our understanding and interpretation of section 1 of the Charter and the permissible scope of government interference with fundamental freedoms. To that end, it might serve as a reminder that section 1 was conceived of as setting a high threshold to justify rights violations - as an exception to the guaranteed rights and freedoms contained in the Charter, and not the rule.

Further, the discussion of Alberta's Critical Infrastructure Defence Act, adopted in response to blockades and protests aimed at pipeline development, ${ }^{20}$ coupled with the existence of

\footnotetext{
${ }^{20}$ Jennifer Koshan, Lisa Silver, \& Jonette Watson Hamilton, "Protests Matter: A Charter Critique of Alberta's Bill 1 " (9 June 2020), online (blog): ABlawg.ca <ablawg.ca/2020/06/09/protests-matter-a-charter-critique-of-albertas-
} 
similar legislative trends in other jurisdictions, ${ }^{21}$ and the rise of climate protests, ${ }^{22}$ makes this work relevant to activism, and the issues it responds to, beyond animal rights. This article comes at a time when public attention to animal agriculture and meat production is at an all-time high, not only with respect to the treatment of farmed animals, but also regarding working conditions for humans in light of the high incidence of COVID-19 infections in slaughterhouses in the US and Canada, ${ }^{23}$ and the demonstrated connections between industrial farming, animal confinement, and the spread of zoonotic diseases. ${ }^{24}$ Indeed, it is no longer possible to turn a blind eye to the risks to human health associated with industrial animal farming and the relationships between intensive animal agriculture, the spread of zoonotic pathogens, and the increased microbial resistance that results from the regular, prophylactic use of antibiotics in food production. ${ }^{25}$ Likewise, with respect to our natural environment, the connection between industrial animal farming and environmental harm is clear: "the animal agriculture industrial complex is one of the major causes

bill-1/>; Alberta, Legislative Assembly, Hansard, 30th Leg, 2nd Sess (26 February 2020) at 12 [Alberta Hansard (26 February 2020)].

${ }^{21}$ See e.g US, SF 2235, An Act relating to criminal acts committed on or against critical infrastructure and providing penalties, 87st Gen Assem, Reg Sess, Iowa, 2018 (enacted); US,HB 3557, An Act relating to civil and criminal liability for engaging in certain conduct involving a critical infrastructure facility; creating criminal offences, 2019, 86th Leg Assem, Reg Sess, Tex, 2019 (enacted); US, SB 2044, AN ACT to amend and reenact section 12.1-21-06 of the North Dakota Century Code, relating to tampering with or damaging a critical infrastructure facility or a public service; and to provide a penalty, 2019, 66th Leg Assem, Reg Sess, ND, 2019 (enacted).

${ }^{22}$ See e.g. Sandra Laville \& Johnathan Watts, "Across the globe millions join biggest climate protest ever" (21 September 2019), online: The Guardian <theguardian.com/environment/2019/sep/21/across-the-globe-millions-joinbiggest-climate-protest-ever>; Somini Sengupta, "Protesting Climate Change, Young People Take to the Streets in a Global Strike" (20 September 2019), online: The New York Times <nytimes.com/2019/09/20/climate/global-climatestrike.html>.

${ }^{23}$ Sarah Berger Richardson, "Worked to the Bone: COVID-19, the agrifood labour force, and the need for more compassionate post-pandemic food systems" in Colleen M. Flood et al, eds, Vulnerable: The Law, Policy and Ethics of COVID-19 (Ottawa: University of Ottawa Press, 2020) 501.

${ }^{24}$ See e.g. Damian Carrington, "Coronavirus: world treating symptoms, not cause of pandemics, says UN" (6 July 2020), online: The Guardian <theguardian.com/world/2020/jul/06/coronavirus-world-treating-symptoms-not-causepandemics-un-report>; United Nations Environment Programme, "Preventing the Next Pandemic: Zoonotic Diseases and How to Break the Chain of Transmission" (2020), online (pdf): United Nations Environment Programme <wedocs.unep.org/bitstream/handle/20.500.11822/32316/ZP.pdf?sequence=1\&isAllowed=y>; Silviu Petrova et al, "Post COVID-19: a solution scan of options for preventing future zoonotic epidemics" (2020) online (pdf): $O S F<$ osf.io/5jx3g/>.

${ }^{25}$ See Romain Espinosa, Damian Tago, \& Nicolas Treich, "Infectious Diseases and Meat Production” (2020) 76 Enviro \& Resource Economics 1019. 
of human-induced global greenhouse gas emissions." 26 Those concerned about our changing climate should be troubled by legislation that seeks to shield the activities of an industry that is a significant contributor to drought, environmental degradation, ${ }^{27}$ and global warming. ${ }^{28}$

Finally, this article makes a small but needed contribution to the growing Canadian literature on agricultural exceptionalism, and the historic privileging of the agricultural industry by legislators and policymakers. In Canada, while some research examines the "special sociolegal place of agriculture within regimes governing ... diverse policy fields, ${ }^{29}$ the economic and cultural importance of animal agriculture, and the "broader [legislative] trend of insulating agriculture form the demands of a range of social justice imperatives," merits further attention. ${ }^{30}$ While I do not explicitly engage in this discussion, the section 1 analysis draws on other examples of exceptional treatment of the agricultural industry by legislators and courts in the context of limiting the labour protections guaranteed by the Charter. ${ }^{31}$ Moreover, ag-gag legislation is, in essence, about immunizing a specific, self-regulating, private industry from public scrutiny so as to protect its economic viability. ${ }^{32}$

\footnotetext{
${ }^{26}$ Núria Almiron, "Meat taboo: Climate change and the EU meat lobby" in Jason Hannan, ed, Meatsplaining: The Animal Agriculture Industry and the Rhetoric of Denial (Sydney: Sydney University Press, 2020) 163 at 163.

${ }^{27}$ See Kathryn Gillespie, The Cow With Ear Tag \#1389 (Chicago: University of Chicago Press, 2019) at 193 [Gillespie, \#1389].

${ }^{28}$ See generally Trevor J Smith, "Corn, Cows, and Climate Change: How Federal Agriculture Subsidies Enable Factory Farming and Exacerbate U.S. Greenhouse Gas Emissions" (2019) 9:1 Washington J of Environmental L \& Policy 26; Heather McLeod-Kilmurray, "Does the Rule of Ecological Law Demand Veganism: Ecological Law, Interspecies Justice, and the Global Food System" (2019) 43:3 Vermont L Rev 455.

${ }^{29}$ Jessica Eisen, "Down on the Farm: Statuts, Exploitation, and Agricultural Exceptionalism" in Charlotte Blattner, Kendra Coulter, \& Will Kymlicka, eds, Animal Labour: A New Frontier of Interspecies Justice? (Oxford: Oxford University Press, 2020) 139 at 143. For examples of Canadian agricultural exceptionalism in matters animal than the treatment of animals see also Laura Alford \& Sarah Berger Richardson, "Right-to-Farm Legislation in Canada: Exceptional Protection for Standard Farm Practices" (2019) 50:1 Ottawa L Rev 131; Michael Trebilcock \& Kristen Pue, "The Puzzle of Agricultural Exceptionalism in International Trade Policy" (2015) 18:2 J Intl Econ L 233.

${ }^{30}$ Eisen, supra note 29 at 142.

${ }^{31}$ See Dunmore v Ontario (Attorney General), 2001 SCC 94 at para 181 [Dunmore].

${ }^{32}$ On a related note, a private member's bill currently making its way through Parliament would extend exemptions from the application of the carbon tax to fuels most frequently used by farmers. See Bill C-206, An Act to amend the Greenhouse Gas Pollution Pricing Act (qualifying farming fuel), 1st Sess, 43rd Parl, 2020 [passed in the House in June 2021 and reinstated following the 2021 election].
} 


\section{Ag-Gag in Canada and the Constitutional Protection of Animal Rights Activism}

This Part provides an overview of the legislation in question, in Alberta and Ontario. ${ }^{33}$ In setting out the legislative landscape, this Part also summarizes the argument, set out in my previous work, that animal rights activism is constitutionally protected speech and that by suppressing the activities of activists, ag-gag legislation constitutes a clear limit to section 2(b) of the Charter, the right to freedom of expression.

As explained, Alberta's Bill 27 created harsh penalties, including fines of up to $\$ 10,000$ for a first offence, $\$ 25,000$ for a second, and up to $\$ 200,000$ for a corporation, as well as potential imprisonment for up to six months, for trespassing onto private property. ${ }^{34}$ The law also deems entry under false pretences trespassing. ${ }^{35}$ Bill 27 became law in December 2019. ${ }^{36}$ Importantly, while recent occupations by animal rights activists of industrial animal farms were a significant driver of Bill 27, ${ }^{37}$ the trespass amendments were not limited to agricultural property. In fact, due its broad wording and application, the Alberta amendments make it illegal to gain entry onto and, indirectly, to conduct undercover investigations on any private property in the province, subjecting offenders to those severe penalties.

\footnotetext{
${ }^{33}$ Note, however, that Canadian ag-gag legislation is not limited to these jurisdictions. There is legislation effectively prohibiting roadside vigils and slaughterhouse protests in force in Manitoba. See Bill 62, supra note 4, the wording of which mirrors the transport provisions of Ontario's law. Legislation has also been adopted in Prince Edward Island. See Bill No 120, An Act to Amend the Animal Health Act, 1st Sess, 66th Leg, PEI, 2020 (assented to December 2020), RSPEI 2020, c 86; Bill No 124, An Act to Amend the Animal Welfare Act, 1st Sess, 66th Leg, PEI, 2020 (assented to December 2020), RSPEI 2020, c 86. PEI's legislation, while it indirectly limits animal rights activism on farms, may not be as constitutionally problematic from a Charter perspective as the statues examined here, but it nevertheless singles out one industry for special protection. Combined, all these laws evince a growing legislative trend in Canada. I have chosen to focus on Alberta and Ontario as they were the first Canadian jurisdictions to adopt these kinds of laws and, in doing so, created serious offences with troubling consequences.

${ }^{34}$ See Bill 27, supra note 1.

${ }^{35} \mathrm{Ibid}$.

${ }^{36}$ Alberta, Legislative Assembly, Hansard, 30th Leg, 1st Sess (28 November 2019) [Alberta Hansard (28 November 2019)].

${ }^{37}$ See the discussion below, in Part 3, on the legislative objective.
} 
That said, Alberta legislative developments in the form of trespass legislation also specifically target, and protect, animal agriculture. Alongside Bill 27, Alberta adopted a new regulation, the Biosecurity Regulation, ${ }^{38}$ under its Animal Health Act. ${ }^{39}$ Similar to Bill 27, the regulation prohibits unauthorized entry into a "biosecurity area" where livestock is or will be housed, ${ }^{40}$ subject to even higher fines than general trespass — up to $\$ 15,000$ for a first offence, and up to $\$ 30,000$ and/or imprisonment for up to a year for a second ${ }^{41}$ Corporations, for their part, are liable to a fine of up to $\$ 200,000 .{ }^{42}$ The definition of "livestock" lists 29 different kinds of animals used for commercial purposes, including "beef cattle," "dairy cattle," “poultry," "swine," and fish kept pursuant to a "commercial fish culture licence." ${ }^{43}$ Like Bill 27, where a person obtains authorization to enter based on false pretences, that person is deemed to have entered without authorization. ${ }^{44}$ Further, the regulation also indirectly prohibits, subject to the same penalties, interference with transport vehicles carrying animals and interaction with the animals being transported. ${ }^{45}$

Soon after the trespass prohibitions were adopted, in February 2020, the Alberta government introduced Bill 1, the Critical Infrastructure Defence Act. ${ }^{46}$ That act purports to "reinforce public safety" and to "strengthen penalties against those who would lawlessly trespass or jeopardize public safety by seeking to block critical public infrastructure, including roadways, railways, and other important infrastructure." ${ }^{47}$ Even broader than Bill 27, which is limited to

\footnotetext{
${ }^{38}$ Alta Reg 185/2019 [Biosecurity Regulation].

${ }^{39}$ SA 2007, c A-40.2.

${ }^{40}$ Biosecurity Regulation, supra note 38, s 2.

${ }^{41}$ Ibid, s 4(1)(a).

${ }^{42}$ Ibid, s 4(1)(b).

${ }^{43}$ Ibid, s 1(1)(b).

${ }^{44}$ Ibid, s 2(5).

${ }^{45}$ Ibid, ss 1(c), 2.

${ }^{46}$ Supra note 2.

${ }^{47}$ Alberta, Legislative Assembly, Hansard, 30th Leg, 2nd Sess, (25 February 2020) at 4.
} 
private property, the Critical Infrastructure Defence Act prohibits the wilful obstruction, interruption, or interference with "any essential infrastructure," 48 the definition of which includes highways and agricultural operations. ${ }^{49}$ As explained, like the Biosecurity Regulation, the impact of the Critical Infrastructure Defence Act, where animal rights activism is concerned, is to prohibit roadside vigils by members of the Animal Save Movement and similar groups. Bill 1 was adopted in June $2020 . .^{50}$

Ontario has seen a similar legislative move. In December 2019, the Ontario government tabled Bill 156, the Security from Trespass and Protecting Food Safety Act, 2019. ${ }^{51}$ The Act makes it an offence to enter an "animal protection zone" without authorization and deems entry based on false pretences an offence. ${ }^{52}$ An "animal protection zone" is a designated area on a farm, an "animal processing facility," or a "prescribed premises," where "animals may be kept or located. $" 53$ The trespass provisions are meant to apply to unauthorized entry onto farms by animal rights activists. Bill 156 also targets activism related to animals in transit; it is an offence to "stop, hinder, obstruct or otherwise interfere with a motor vehicle transporting farm animals," 54 and to “interfere or interact with a farm animal being transported by a motor vehicle without the prior consent of the driver of the motor vehicle." 55 Like in Alberta, that provision is clearly aimed at the activities of the Animal Save Movement, members of which regularly interact with animals on

${ }^{48}$ CIDA, supra note 2 , s 2 .

49 Ibid, s 1.

${ }^{50}$ Alberta, Legislative Assembly, Hansard, 30th Leg, 2nd Sess, (28 May 2020) at 869.

${ }^{51}$ Bill 156, An Act to protect Ontario's farms and farm animals from trespassers and other forms of interference and to prevent contamination of Ontario's food supply, 1st Sess, 42nd Leg, Ontario, 2020 (assented to 18 June 2020) SO 2020, c 9 [Bill $156(\mathrm{ON})]$.

${ }^{52} \mathrm{Ibid}$, s 5(2).

${ }^{53}$ Ibid, s 2.

${ }^{54}$ Ibid, s 6(1).

55 Ibid, s 6(2). 
trucks by talking to them, petting them, and giving them water on hot days. ${ }^{56}$ Bill 156 was adopted in June 2020.

While the provisions related to interfering with a transport vehicle went into effect upon royal assent, regulations were subsequently adopted to clarify the circumstances that amount to entry under false pretences. ${ }^{57}$ Accordingly, a person who makes a false statement in order to gain access to a farm, animal processing facility, or prescribed premises, commits an offence. ${ }^{58}$ The same goes for individuals who make false statements in order to obtain employment. ${ }^{59}$ However, the regulation contains two exceptions: one for "news media" journalists,${ }^{60}$ and one for what it terms "whistle-blowers." According to the latter, where a person employed at a facility makes a false statement, consent to enter "shall not be considered to have been obtained under false pretences" if, among other things, the person "[obtains] information or evidence of harm to a farm animal $\ldots$ and $\ldots$ the person discloses the information or evidence [of harm] to a police officer or other authority as soon as practicable after obtaining the information or evidence." 61

At first glance, this provision seems to imply that animal rights activists who make false statements in order to gain employment on farms to document and disseminate animal abuse are not captured by the trespass, or false pretences, provision. But a closer read makes clear that only those individuals who actually document harm and immediately turn that information over to law enforcement authorities are exempted from the commission of an offence. This is what is known as a "quick report law," or a "mandatory report law." ${ }^{62}$ While quick report laws may seem to favour animal interests by ensuring that all abuse is reported right away, "in intent and effect these

\footnotetext{
${ }^{56}$ See $R v$ Krajnc, 2017 ONCJ 281 at para 2 [Krajnc].

${ }^{57}$ See General, O Reg 701/20 [Reg 701/20].

${ }^{58} \mathrm{Ibid}$, s 9.

${ }^{59} \mathrm{Ibid}, \mathrm{s} 10$.

${ }^{60} \mathrm{Ibid}$, s 11

${ }^{61} \mathrm{Ibid}, \mathrm{s} 12$.

${ }^{62}$ Marceau, supra note 11.
} 
laws impede journalistic and other undercover investigations of food producing facilities" by making it impossible to document repeated and persistent patterns of animal abuse, and undermining the point in going undercover at an animal use facility. ${ }^{63}$ Moreover, the provision states that unless and until the moment a person actually witnesses and documents animal abuse, they are not covered by the exception. Thus, an individual who works at a facility but does not witness abuse right away could be prosecuted, until they do. Only once they actually document abuse could they meet the exception, and only provided they turn the information over to the authorities. The exception, in other words, is extremely narrow, and does little to protect the work of those committed to exposing the violence of industrial animal farming. With respect to journalists, they are only exempted if their actions do not cause "harm to a farm animal, harm with respect to food safety or harm to an individual." ${ }^{64}$ The term "harm to an individual" is defined as "emotional or psychological injury, including undue stress"-in other words, the documented consequences of an individual being recorded abusing animals and, in some cases, fired as a result, ${ }^{65}$ or where an owner is concerned, of the negative publicity associated with an exposé. This, too, makes for a narrow exception.

As I have suggested, Canadian ag-gag laws constitute a clear limit to the Charter right to freedom of expression, as it has been interpreted by courts and scholars. ${ }^{66}$ Prohibitions on demonstrations on public roads and sidewalks outside of slaughterhouses and limits on specific messages to gain access to a property are content-based restrictions and, accordingly, constitute prima facie limits to section 2(b) of the Charter ${ }^{67}$ Moreover, both activities relate to the underlying

\footnotetext{
63 Ibid at $1340,1341$.

${ }^{64}$ Reg 701/20, supra note 57, s 11.

${ }^{65}$ See Ted Genoways, The Chain: Farm, Factory, and the Fate of Our Food (New York: Harper, 2014) (discussing the consequences of undercover investigations on individuals exposed as animal abusers at 135-143).

${ }^{66}$ See Lazare, supra note 7.

67 See Irwin Toy Ltd v Quebec (Attorney General), [1989] 1 SCR 927, 58 DLR (4th) 577 [Irwin Toy].
} 
reasons why the Charter protects freedom of expression. ${ }^{68}$ As Maneesha Deckha explains, the activities of the Animal Save Movement are an "exercise in truth telling." 69 The same might be said of undercover investigations of industrial farm operations and the dissemination and viewing of video and photographic evidence of cruel farming practices. Indeed, the Canadian public has a right to know how its food is produced and to make consumer choices accordingly. ${ }^{70}$ Whereas freedom of expression is about protecting "the individual's freedom to communicate with others," 71 prohibiting the activities of those who aim to make public the violence of industrial animal farming cuts off a crucial and "extraordinarily effective" source of information, "critical to public discourse," and with the potential to reveal "the unsavory practices of a wealthy and powerful industry to public scrutiny." 72

Animal rights activism is also political in nature; Kathryn Gillespie writes that "the act of witnessing animals' predicaments, and then sharing their stories, is a political act that resists the erasure of individual animal lives, suffering, and deaths." 73 Timothy Pachirat, for his part, suggests that uncovering animal suffering in hidden spaces like farms and slaughterhouses confronts viewers with "a politics of sight, defined as organized, concerted attempts to make visible what is hidden ... in order to bring about social and political transformation."74 This kind of political

\footnotetext{
${ }^{68}$ The underlying reasons are truth-telling, participation in political and democratic discourse, and individual selffulfilment and human flourish. See ibid.

${ }^{69}$ Deckha, supra note 10 at 83.

${ }^{70}$ See Kattenburg v Canada (Attorney General), 2019 FC 1003; Marie-Claude Desjardins \& Sabrina TremblayHuet, "The Consumers' Right to Information about Animal Welfare: The Canadian Framework for Labelling of Food Products of Animal Origin" in Heather McLeod-Kilmurray, Angela Lee \& Nathalie Chalifour, eds, Food Law and Policy in Canada (Toronto: Carswell, 2019) 287; Richard Moon, "Limits on Constitutional Rights: The Marginal Role of Proportionality Analysis" (2017) 50:1 Israel LR 49 ("Freedom of expression is instrumental to the realization of social goods such as public knowledge" at 54) [Moon, "Limits"].

${ }^{71}$ Moon, "Limits", supra note 70 at 53.

${ }^{72}$ See Alan K Chen \& Justin Marceau, "High Value Lies, Ugly Truths, and the First Amendment" (2015) 68:6 Vand L Rev 1435 at 1466, 1456-1457 [Chen \& Marceau, "High Value Lies"].

${ }^{73}$ Kathryn Gillespie, "Witnessing Animal Others: Bearing Witness, Grief, and the Political Function of Emotion" (2016) 31:3 Hypatia 572 at 576 on the "politics of food production"; see generally Gillespie, \#1389, supra note 27.

74 Timothy Pachirat, Every Twelve Seconds: Industrialized Slaughter and the Politics of Sight (New Haven: Yale University Press, 2011) at 15.
} 
activity is particularly salient in the context of industry self-regulation and a lack of government oversight where industrial animal agriculture in Canada is concerned. ${ }^{75}$ Moreover, Canada has the reputation of having the worst agricultural animal transport rules in the developed world, ${ }^{76}$ something that animal rights activists seek to expose to the broader public in order to stimulate legislative reform. ${ }^{77}$ The activities of animal rights activists might also be seen as a form of individual self-fulfilment and human flourishing. As I have written, “sharing one's deep moral convictions about animal use and exploitation, whether in the hopes of persuading others or simply as a means of personal fulfilment, surely promotes individual autonomy and human flourishing."78 Canadian ag-gag legislation targets not only the messages of animal rights activists, but also the means of creating that message. The prohibition on entry based on false pretences - or the fact that entry on false pretences is deemed trespass - also limits protected speech, both in purpose and effect, as does the "quick report" provision of the Ontario regulation. As Alan K. Chen and Justin Marceau suggest in their analysis of American ag-gag legislation, the provisions amount to a prohibition on telling a lie in order to gain access to an animal-use facility. ${ }^{79}$ In other words, the legislation dictates permissible and impermissible speech, thus constituting a content-based restriction and a prima facie limit to section 2(b). The effect of the legislation is to prevent speech precedent to the type of expression carried out by undercover activists - that is, expression that

\footnotetext{
${ }^{75}$ See Lazare, supra note 7; Peter Sankoff, “Canada's Experiment with Industry Self-Regulation in Agriculture: Radical Innovation or Means of Insulation?” (2019) 5 Can J Comparative \& Contemporary L 299; Katie Sykes, "Rethinking the Application of the Canadian Criminal Law to Factory Farming" in Peter Sankoff, Vaughan Black \& Katie Sykes, Canadian Perspectives on Animals and the Law (Toronto: Irwin Law, 2015) 33; Lesli Bisgould, Animals and the Law (Toronto: Irwin Law, 2011) at c 71.

76 See Maureen Harper, "Legalized cruelty: the gaps in Canada's animal transport laws" (26 May 2017) online: iPolitics <ipolitics.ca/2017/05/26/legalized-cruelty-the-gaps-in-canadas-animal-transport-laws/> ("In my opinion, Canada has the worst animal transport regulations amongst developed nations. This is based on current allowable maximum transport times for all animals. And unfortunately, the proposed changes will still leave Canada in this unenviable position. Canadians expect far more of their government with respect to protection of animal welfare, and our animals deserve far better").

${ }^{77}$ See Deckha, supra note 10.

${ }^{78}$ See Lazare, supra note 7 at 102. .

${ }^{79}$ See Chen \& Marceau, "High Value Lies", supra note 72.
} 
seeks to tell the truth, engages political discourse, and promotes the self-fulfilment and human flourishing of activists.

Richard Moon explains that a meaningful commitment to freedom of expression depends on the existence of conditions that enable individuals to make "reasoned and independent judgments and have access to different opinions and reliable factual information." 80 Limiting that access, as ag-gag legislation does, necessarily impacts the rights of both animal rights activists, in their efforts to obtain and share information, and members of the general public, who are prevented from accessing that information. In short, in both purpose and effect, Canadian ag-gag laws amount to an infringement of section 2(b) of the Charter by preventing members of the public from producing and "[receiving] and [assessing] ideas and information without interference from the state." 81 What remains to be determined is whether these limits are justifiable in the interests of a free and democratic society—-that is, under section 1 of the Charter.

\section{Contextualizing Ag-Gag and the Section 1 Analysis}

This Part briefly introduces the section 1 analysis as developed by the courts and interpreted in the relevant literature and sets out the considerations that might inform a court's inquiry into the justifiability of ag-gag legislation and its inherent limit on Charter rights. Before engaging in the balancing test established in $R v$ Oakes,${ }^{82}$ it is worth being explicit about what is really at stake when Canadian courts carry out the proportionality test mandated by section 1 and courts will often engage in this contextual inquiry before embarking on the Oakes analysis, which "clarified the ... interpretive methodology for Charter cases." 83 Importantly, in addition to the

\footnotetext{
${ }^{80}$ Richard Moon, “Does Freedom of Expression Have a Future?" in Emmett MacFarlane, ed, Dilemmas of Freedom of Expression (Toronto: University of Toronto Press, 2021) 15 at 15.

${ }^{81}$ Moon, "Limits", supra note 70 at 58.

${ }^{82}$ Supra note 18.

${ }^{83}$ Sujit Choudhry, "So What Is the Real Legacy of Oakes? Two Decades of Proportionality Analysis under the Canadian Charter's Section 1" (2006) 34 Sup Ct L Rev 501 at 501.
} 
analytical steps, Oakes established "the need to tailor judicial review to the unique context of each case." ${ }^{" 44}$ Context is the "touchstone of section 1." $" 85$

Rights adjudication and constitutional challenges do not take place in a vacuum; evaluating limits on expression typically entails a judgment about the value or harm inherent in a particular social practice. ${ }^{86}$ Indeed, the rigour with which courts will examine a restriction on fundamental freedoms will often depend on a number of factors, including the nature of the right being limited. ${ }^{87}$ The speech at issue here - speech by animal rights activists and advocates - may relate to what members of the public choose to buy at the grocery store. It is not, however, profit-driven speech, which lies "far from the 'core' of freedom of expression values," and which may be easier to justify limiting.$^{88}$ Rather, despite the legislation's purported aims, the background makes it clear that the message targeted is both political and informational in nature; as discussed above, animal rights activism can inform deeply personal decisions, such as what foods to eat, what to feed one's children, and ultimately, what ethical relationships with animals look like. ${ }^{89}$ In terms of informational value, the issues highlighted by activists might drive consumers to ask what kinds of animal husbandry practices they want to support with their dollars. Where politics are concerned, the images revealed by activists might influence observers to think about how the law governs the treatment of farmed animals,${ }^{90}$ and how lawmakers might do better. The value of this speech to members of the public means that limits on it should be more difficult to justify. As the

\footnotetext{
${ }^{84}$ Ibid at 503.

${ }^{85}$ Ibid at 521.

${ }^{86}$ See Moon, "Limits", supra note 70 at 58.

${ }^{87}$ See $R v$ Bryan, [2007] 1 SCR 527 at para 10, 276 DLR (4th) 513.

${ }^{88}$ See RJR-MacDonald Inc v Canada (Attorney General), [1995] 3 SCR 199 at 74, 127 DLR (4th) 1 [RJRMacDonald].

${ }^{89}$ See Lazare, supra note 7.

${ }^{90}$ In short, it does not. In Canada, the treatment of animals on farms is governed by non-binding codes of practice, created primarily by the members of the agriculture industry and relevant stakeholders, such as fast food restaurants and grocery chains. See Sankoff, supra note 75; National Farm Animal Care Council, (2020), online: National Farm Animal Care Council <nfacc.ca/>.
} 
Supreme Court has repeatedly asserted, ${ }^{91}$ "political speech lies at the core of section $2(b) \ldots$ and laws which restrict it do not warrant any deference.",92

In a similar vein, the type of legislation under review also affects the court's approach. Constitutional adjudication always involves some "form of interest-balancing,"93 but where legislation aims to balance the competing interests of different segments of the population —animal rights activists, agricultural producers, and the general public_-governments will typically benefit from more leeway in constitutional review. ${ }^{94}$ In other words, the polycentric nature of the legislation could suggest a more flexible standard of justification and an easier onus on the government, which bears the burden of proving that legislative limits to rights are justified. ${ }^{95}$ This would not, however, absolve the government of the need to produce clear evidence at each stage of the Oakes test. While the standard may be less demanding in non-criminal cases, Oakes set out a "stringent standard of justification" for limiting fundamental freedoms, ${ }^{96}$ and made "empirics central to every stage of the Oakes test." ${ }^{, 97}$ As Justice McLachlin (as she then was) confirmed more than a decade later, justification under section 1 involves a "reasoned demonstration" that the impact of a law on Charter rights is proportionate to its objectives and means of achieving them. ${ }^{98}$ "In short, s. 1 is an exercise based on the facts of the law at issue and the proof offered of its justification, not on abstractions." 99 Thus, section 1 involves an inquiry into the facts and the

\footnotetext{
${ }^{91}$ See e.g. Libman v Quebec (Attorney General), [1997] 3 SCR 569 at paras 40-43, 151 DLR (4th) 385; Harper v Canada (Attorney General), 2004 SCC 33 at paras 14-16, 25; Thomson Newspaper Co. v. Canada (Attorney General), [1998] 1 SCR 87 at paras 24-26, 159 DLR (4th) 385.

${ }^{92}$ Choudhry, supra note 83 at 515.

${ }^{93}$ Ibid at 512.

${ }^{94}$ See RJR-MacDonald, supra note 88.

95 See Kent Roach, The Supreme Court on Trial: Judicial Activism or Democratic Dialogue, rev'd ed (Toronto: Irwin Law, 2016) for an in-depth discussion of the varying levels of deference involved in judicial review of social policy.

${ }^{96}$ Oakes, supra note 18 at 136, cited in Choudhry, supra note 83 at 506.

${ }^{97}$ Choudhry, supra note 83 at 522 [emphasis in original].

${ }^{98}$ RJR-MacDonald, supra note 88 at para 129.

${ }^{99}$ Ibid at para 133.
} 
evidence proffered by the government in support of those facts. With respect to ag-gag legislation, it demands evidence of the reasonableness of limiting activism in the ways the governments of Alberta and Ontario have chosen.

Justification of Charter limits is a question of balance. Where freedom of expression is limited, the proportionality test under section 1 seeks to establish the line between engagement, or permissible speech, and manipulation, or the type of speech that may be justifiably restricted. ${ }^{100}$ The ultimate question for courts here is "whether the expression appeals to audience judgment or whether it instead aims to manipulate or influence the audience at a non-cognitive level,"101 the latter being the type of speech that the government may rightfully limit; the line between the two will be drawn in different places by different people. ${ }^{102}$ The remainder of this article is premised on the belief that the expression limited by Canadian ag-gag legislation does not rise to the level of manipulation, but rather, makes a meaningful contribution to public discourse on a matter of observable fact. Indeed, more than engagement or permissible speech, animal rights activism, as targeted by the legislation in question, is the kind of speech that the Charter is meant to protectunpopular perhaps, but crucial, in the eyes of the speakers, to truth-seeking, democratic discourse, and individual self-fulfilment and human flourishing. ${ }^{103}$ In the final balance, it is doubtful that the objectives of ag-gag legislation, which the next Part explores, outweigh these fundamental interests.

\footnotetext{
100 See Moon, "Limits", supra note 70 at 57.

${ }^{101}$ Ibid at 60. See also Richard Moon, "What happens when the assumptions underlying our commitment to free speech no longer hold?" (2019) 28:1 Const Forum 1 for a clear explanation of the purposes of protecting freedom of expression and what constitutes an appropriate reason to limit speech.

102 See Moon, "Limits”, supra note 70 at 57.

${ }^{103}$ See Irwin Toy, supra note 67 at 973-975 (setting out the underlying purposes of the Charter's protection of freedom of expression).
} 


\section{Protecting Industrial Animal Agriculture and Limiting Expression are not Pressing and Substantial Objectives}

The first step of the Oakes test is an assessment of whether the government has demonstrated ${ }^{104}$ that the limit to rights is "pressing and substantial." 105 For Chief Justice Dickson, a pressing and substantial objective is one that "furthers the values of the "free and democratic society' referred to by the text of section $1 .{ }^{" 106}$ In the years following Oakes, the test was a stringent one, with rights limitations only being justifiable in exceptional situations. ${ }^{107}$ With time, however, the standard was loosened; legislative objectives need only be "valid" or "sufficiently important" to withstand section 1 scrutiny. ${ }^{108}$ The current concept of a proper objective has been described as one that "is intended to realize societal objectives that are in line with the values of the state in general and are sensitive to the place of human rights in the general social arrangement." ${ }^{109}$ Thus, a law will meet the first requirement of Oakes where it aims to achieve objectives in line with social values.

Since Oakes, the debate around the need for a pressing and substantial objective may centre less on the standard of justification and more on the requirement of compelling evidence. Stated otherwise, given the empirical nature of the section 1 analysis, it is not enough for a government to merely assert, in the abstract, that legislation aims to achieve a particular aim or policy outcome. Rather, "[in] determining whether the objective of the law is sufficiently important to be capable of overriding a guaranteed right, the court must examine the actual objective of the law." 110 Indeed,

\footnotetext{
${ }^{104}$ It is worth being express that the burden of proof under section 1 always lies on the government attempting to justify a limit to Charter rights.

105 Oakes, supra note 18 at 138-39.

${ }^{106}$ Choudhry, supra note 83 at 505.

107 See Ibid at 506.

${ }^{108}$ Ibid at 509-510 [references omitted].

${ }^{109}$ Aharon Barak, "Proportional Effect: The Israeli Experience" (2007) 57:2 UTLJ 369 at 371.

${ }^{110}$ RJR-MacDonald, supra note 88 at para 133.
} 
"rights can only be justifiably limited in response to concrete, precise and real problems or harms whose existence can be demonstrated to the satisfaction of a court through the normal trial process." 111 The following paragraphs unpack the objectives of Canadian ag-gag legislation and suggest that where some of the stated objectives are concerned, there is little evidence supporting the purported harms. However, as legislation rarely fails at the first stage of the Oakes test, ${ }^{112}$ the main purpose of this part is to identify the legislative objectives, as they inform the later parts of the analysis.

The speed with which Alberta's Bill 27 (the trespass amendments) was tabled and adopted means that legislative intent may be difficult to uncover. But the legislative debates are nevertheless illuminating with respect to the objectives, two of which were made express by members of the legislative assembly. Bill 27 was introduced by the Hon. Doug Schweitzer, Minister of Justice, who made clear from the outset that the legislation aims, firstly, to protect property owners from a perceived increase in rural crime: “...we need to make sure that Albertans have the strongest possible property rights here in the province of Alberta. It's integral to make sure that property rights are respected, that landowners can feel safe in their homes knowing that law-abiding citizens are protected." ${ }^{113}$ Hansard suggests, moreover, that Bill 27 is about protecting a certain category of property owners: "It's going to protect our farmers. It's going to protect our homeowners across this province." ${ }^{114}$ Second, Bill 27, despite that it applies to non-agricultural property as well, is expressly about protecting biosecurity and the safety of Alberta's food system; ${ }^{15}$ the debates acknowledge that entry onto animal farms without the proper precautions

\footnotetext{
111 Choudhry, supra note 83 at 523.

${ }^{112}$ But see $R$ v Big M Drug Mart Ltd, [1985] 1 SCR 295 at 352, 18 DLR (4th) 321; Canada Without Poverty v. AG Canada, 2018 ONSC 4147 at paras 64-65; CCLA v Attorney General of Ontario, 2020 ONSC 4838.

113 Alberta, Legislative Assembly, Hansard, 30th Leg, 1st Sess, (19 November 2019) at 2336.

114 Alberta Hansard (28 November 2019), supra note 36 at 2639.

115 See Alberta, Legislative Assembly, Hansard, 30th Leg, 1st Sess, (26 November 2019) at 2578.
} 
could create a risk of transferring diseases, such as swine flu, between animals and humans, and from farm to farm. ${ }^{116}$ Finally, while not an explicitly stated objective, an opposition MLA raised the idea that in addition to property and biosecurity, Bill 27 might in fact be an "effort to ... stifle dissent." 117 Before turning to the validity of each of these objectives, it is worth looking at the similar goals of Alberta's Bill 1, as well as those of Ontario's parallel legislation.

The leadup to Bill 1, now the Critical Infrastructure Defence Act, ${ }^{118}$ made its objectives quite clear. The Bill appears to have been tabled in response to public protests, in the form of blockades of pipelines and railways, in support of Indigenous communities affected by proposed pipeline construction. ${ }^{119}$ Hansard confirms these goals: referring to infrastructure being barricaded, and prosperity being impaired by "by green zealots and eco-radical thugs," the legislation aims to "discourage the illegal protesters, who are scaring away investors, shutting down a large part of our economy, and potentially jeopardizing the public safety of the workers on rail lines and critical infrastructure projects." ${ }^{120}$ The principal goal of Bill 1, in other words, is to "[take] action to defend our vital economic interests." 121

Bill 156 in Ontario had similar objectives, both stated and unstated. The statute's original title-An Act to protect Ontario's farms and farm animals from trespassers and other forms of interference and to prevent contamination of Ontario's food supply-reveals its primary

\footnotetext{
116 See Alberta, Legislative Assembly, Hansard, 30th Leg 1st Sess, (25 November 2019) at 2524 [Alberta Hansard (25 November 2019)]; See also Alberta Hansard (28 November 2019), supra note 36 at 2639 (referring to the economic costs of biosecurity breaches).

117 Alberta Hansard (28 November 2019), supra note 36 at 2640.

118 CIDA, supra note 2.

${ }^{119}$ See Kieran Leavitt, “'Not in our backyard': Alberta Wet'suwet'en rail blockade meets stiff opposition and shuts down after injunction granted" (19 February 2020), online: The Star <thestar.com/news/canada/2020/02/19/newwetsuweten-rail-blockade-pops-up-in-the-heart-of-canadas-oil-country.html>; Koshan, Silver \& Hamilton, supra note 20; Matthew Black, "Alberta bill targeting blockade protesters passed into law" (17 June 2020) online: CTV News <edmonton.ctvnews.ca/alberta-bill-targeting-blockade-protesters-passed-into-law-1.4988429>.

${ }^{120}$ Alberta Hansard (26 February 2020), supra note 20 at 12.

${ }^{121}$ Ibid at 15.
} 
objectives: the protection of farmers and of the food supply. Hansard confirms these objectives, but also raises additional ones, such as balancing the security of farmers, who sometimes feel unsafe when activists trespass onto their properties, the food supply, and the "right of people to participate in legal protests." ${ }^{122}$ Further, the legislative debates demonstrate that, like Bill 1 in Alberta, the Ontario statute aims to respond to industry concerns, ${ }^{123}$ and to protect economic interests in agriculture. At second reading, the Hon. Ernie Hardeman, Minister of Agriculture, Food, and Rural Affairs, stressed the importance of “Ontario's diverse agriculture sector [as] a significant economic driver...." 124 Accordingly, "[it's] important that we recognize the important role that agri-food businesses play in regional economic development, as they contribute to our broader economy." 125 The legislation thus demonstrates the "government's commitment to protect the health and safety of [the] agri-food sector...." 126 As another majority MPP stated, "protecting agriculture is a non-partisan issue. It's something that we are all supportive of. We all support our farmers. We all support our agriculture industry."127

The legislative objectives apparent from the debates, however, do not end there. While majority MPPs emphasized the express objectives, opposition members pointed to a less obvious legislative goal, that of silencing animal rights activists, protesters, and undercover investigators. The opposition Critic, Agriculture and Food, Rural Development, John Vanthof, suggested that the legislation is "trying to limit the impact of people who are totally opposed to animal

\footnotetext{
122 Ontario, Legislative Assembly, Hansard, 42nd Parl, 1st Sess (10 December 2019) at 6793 [Ontario Hansard (10 December 2019).

123 Ibid at 6797.

124 Ibid at 6795.

125 Ibid at 6795.

${ }^{126}$ Ibid. See also Ontario, Legislative Assembly, Hansard, 42nd Parl, 1st Sess (18 February 2019) at 6944 [Ontario Hansard (18 February 2019)] ("... agriculture is the second-largest industry in Ontario, contributing \$13.7 billion annually to Ontario's GDP and is essential for putting food on the tables of millions of people here and around the world...," citing a motion from the township of Warwick in support of the legislation).

${ }^{127}$ Ontario, Legislative Assembly, Hansard, 42nd Parl, 1st Sess (11 December 2019) at 6820.
} 
agriculture" as well as investigative reporting, ${ }^{128}$ and that it "could be perceived as antiwhistleblower." ${ }^{129} \mathrm{He}$ also pointed out that the "retroactive trespassing part" - that is, the fact that an individual who enters a facility under false pretences is deemed to have trespassed-"has nothing to do with biosecurity." 130 More about this absence of connection between the stated objectives and the impugned measure will be said in the next Part, in the context of the requirement for a rational connection. Likewise, another opposition MPP highlighted the history of ag-gag legislation in the United States, where similar laws, "designed to silence whistle-blowers who reveal animal abuses on industrial farms," 131 and which "effectively cut off an important source of public information and a driver of policy change," 132 have been struck down as contrary to the First Amendment right to free speech. ${ }^{133}$ Another opposition member suggested that the purpose is political - that the government wants to "employ wedge issues to try and pit farmers against animal rights activists" and knows that the legislation will be challenged in court. ${ }^{134}$ Thus, Canadian ag-gag legislation looks a lot like its American counterpart, the objectives of which have been unpacked in the relevant literature; in short, the history, effects, and context of the legislation "all evince a desire to target animal rights activists and sympathetic journalists and subject their political speech to disfavored treatment." 135

The question, then, for each of these apparent purposes, is whether they accord with social values, and whether the government presents "evidence of the real, concrete harms of [the]

\footnotetext{
${ }^{128}$ Ontario Hansard (10 December 2019), supra note 122 at 6806.

${ }^{129}$ Ibid at 6807.

${ }^{130}$ Ibid.

${ }^{131}$ Ontario Hansard (18 February 2019), supra note 126 at 6948.

132 Ibid at 6949.

${ }^{133}$ See Wasden, supra note 14; Herbert, supra note 14; Reynolds, supra note 14.

${ }^{134}$ Ontario Legislative Assembly, Hansard, 42nd Parl, 1st Sess (20 February 2019) at 7026 [Ontario Hansard (20 February 2019)].

${ }^{135}$ Chen \& Marceau, "High Value Lies", supra note 72 at 1470.
} 
prohibited speech." 136 As discussed above, "governments can only justifiably limit constitutional rights to respond to real problems." ${ }^{137}$ Certainly, governments may protect property interests, as they do through both provincial and federal trespass legislation. ${ }^{138}$ The inquiry here, however, is whether the legislation responds to a concrete problem at the level of privacy interests. The legislative debates suggest that farmers have repeatedly expressed concern and anxiety about unauthorized entry onto their properties, which house not only their barns but also their homes. ${ }^{139}$ Undoubtedly, human safety is a legitimate government concern. But the American experience with similar statutes said to protect private property suggests that the "privacy intrusion narrative is oftentimes a canard." ${ }^{140}$ In the legislative committee hearings prior to the adoption of Bill 156, ${ }^{141}$ an animal rights activist with experience trespassing onto farms to occupy barns and document animal suffering explained that activists do not threaten farmer safety:

Animal rights activists are only concerned about exposing the conditions that animals endure. Farmers' homes are very rarely near any animal agriculture operation due to the strong stench of ammonia from the sheds.... [We] only enter the barns where the animals are. We do not need or want to see any human when we're going into these places. ... [The] farms are not next to any houses, and if the houses are nearby, then we choose not to go there. We are only interested in the animals. ... We are not harming anyone. ${ }^{142}$

This testimony supports the idea, set out by Marceau and Chen, that "[the] privacy interests in the open areas of a large, commercial workplace are quite different than the privacy interests in one's bathroom or living room." ${ }^{143}$ Thus, while there may be societal consensus around the value of

\footnotetext{
${ }^{136}$ Choudhry, supra note 83 at 526.

137 Ibid at 528 .

138 See e.g. Criminal Code, RSC 1985, c C-46, s 177; Trespass to Property Act R.S.O 1991, c T.21.

${ }^{139}$ Ontario Hansard (10 December 2019), supra note 128 at 6794.

140 Justin Marceau \& Alan K Chen, "Free Speech and Democracy in the Video Age" (2016) 116:4 Colum L Rev 991 at 1055 [Marceau \& Chen, "Free Speech"].

${ }^{141}$ In the interests of transparency, I should disclose that I, too, took part in this hearing, expressing a similar opinion as the one I outline here.

${ }^{142}$ Ontario, Legislative Assembly, Standing Committee on General Government, "Security from Trespass and Protecting Food Safety Act, 2020”, Official Report of Debates (Hansard), 42-1, No G-25 (8 June 2020) at G-625-G626 [Hansard (8 June 2020)].

${ }^{143}$ Marceau \& Chen, "Free Speech", supra note 140 at 1054.
} 
protecting the privacy of farmers and farm families, the evidence before the legislature appeared to undermine the suggestion that farmer safety and intrusions on their privacy interests are a "real, concrete [harm]."144

Protecting biosecurity and, ultimately, the food system, may, for its part, constitute a pressing and substantial objective in the context of the section 1 analysis, even though, as with the privacy objective, the government may have difficulty meeting its evidentiary burden. Protecting biosecurity in the interests of a safe food system certainly aligns with societal objectives and state values. The leadup to Canadian ag-gag legislation, however, potentially undercuts the pressing nature of the need for these biosecurity measures. In 2017, an Ontario Provincial Court judge rejected the Crown's argument that the activities of the Animal Save Movement-bearing witness to animal suffering during transport and offering pigs water on hot days - pose any kind of risk to the animals, or to the food they are destined to become. ${ }^{145}$ These of course, are the activities targeted by the transport-related provisions in both provinces. ${ }^{146}$ Likewise, the testimony of the same animal rights activist before the committee studying Ontario's legislation casts similar doubt on the risks to biosecurity by farm trespassers. ${ }^{147}$ In her words, "[we] wear full biosecurity gear. We are not harming anyone." ${ }^{148}$ This testimony aligns with the observation, on the part of American feminist geographer Kathryn Gillespie, that "biosecurity [is] more regularly used as an excuse than a legitimate concern," 149 and that "biosecurity is a complicated and ambiguous buzzword used in supporting the denial of access to spaces of agricultural production under the

\footnotetext{
${ }^{144}$ Choudhry, supra note 83 at 526.

${ }^{145}$ See Krajnc, supra note 56 at paras 2-4.

146 See Security from Trespass Act, supra note 3, ss 6(1-3).

${ }^{147}$ In any event, as the following part suggests, the limit on speech inherent in the prohibition on entering a facility under false pretences would not even apply to trespassers.

${ }^{148}$ Hansard (8 June 2020), supra note 142 at G-626.

${ }^{149}$ Gillespie, \#1389, supra note 27 at 34.
} 
real or perceived guise of food safety and disease prevention." ${ }^{150}$ Indeed, Gillespie's conclusions about biosecurity were informed by the experience of seeing dairy farm workers themselves "arrive to work and complete their jobs with no protective gear or precautionary measures to prevent the spread of disease to the animals" $-{ }^{151}$ and this, despite repeatedly being denied access to farms in the name of biosecurity. Nevertheless, and despite these apparent weaknesses in the government's case, a court would likely accept the protection of biosecurity as a pressing and substantial objective. Indeed, the threshold for demonstrating the required objective is notoriously low. ${ }^{152}$ Further, as seen, when the government is mediating between the interests of different groups, it may be "afforded a margin of appreciation to form legitimate objectives." ${ }^{153}$ Moreover, common sense dictates that protecting the food system from contaminants, regardless of the necessity or efficacy of those protections, is a worthwhile government objective. ${ }^{154}$ For that reason, and based the history of section 1 , a court would likely find the purported protection of food safety is enough to pass this first stage of the test.

The same cannot however be said for the objective of prohibiting public protests, as Alberta's Critical Infrastructure Defence Act, Alberta's Biosecurity Regulation, and Ontario's Security from Trespass Act do, or for the apparent objective of stifling activism and information sharing - the effect of prohibiting entry under false pretences. Each of these activities - public protests, demonstrations, and dissemination of information about the brutal treatment of animals

\footnotetext{
150 Ibid at 35.

${ }^{151}$ Ibid at 34. Descriptions of Canadian industrial agriculture echo Gillespie's observations. Referring to similar behaviour by employees on Canadian farms, one activist and experienced undercover investigator has described participants in the animal agriculture industry itself as the biggest threat to biosecurity. See Geoff Regier, "No Glass Walls: Ag Gag Laws in Canada" (delivered at the Canadian Animal Law Conference 2020, 13 September 2020) [unpublished] ("By far, the biggest threat to biosecurity is the industry itself-by far.")

${ }^{152}$ See Michael A Johnson, "Section 1 and the Oakes Test: A Critical Analysis" (2009) 26:1 NJCL 85 at 98; The Honourable Marshall Rothstein, "LECTURE Section 1: Justifying Breaches of Charter Rights and Freedoms" (2000) 27:2 Man LJ 171 at n 10.

${ }^{153}$ Irwin Toy, supra note 67 at 990.

${ }^{154}$ See RJR-MacDonald, supra note 88 at para 158 (for an example of "common sense" reasoning at section 1).
} 
in the food system - is protected by the Charter, under sections 2(b) and 2(c). ${ }^{155}$ Peter Hogg wrote: “... an objective cannot provide the basis for $\mathrm{s.} 1$ justification if the objective is incompatible with the values entrenched by the Charter of Rights." ${ }^{156}$ As in the United States, "[preventing] the public from obtaining this information precludes the dissemination of much needed safety-related information; this cannot be a compelling state interest." ${ }^{157}$ Canadian ag-gag legislation interferes with the public's right to information about the nature of industrial farming practices-information that enables participation in democratic life and is a means of truth-seeking and individual selffulfilment. Even with a heightened level of deference to complex policymaking, limiting these activities, which go to the heart of the right to freedom of expression, is not a valid legislative objective.

Finally, in both Alberta and Ontario, lawmakers have been clear about the economic objectives of all three relevant statutes and the goal of protecting the agricultural industry in particular. ${ }^{158}$ Agriculture is, uncontroversially, an important industry in Canada. ${ }^{159}$ At the same time, the Canadian Charter has not been interpreted to protect economic rights, ${ }^{160}$ including the right to earn a living, ${ }^{161}$ or the right to property. ${ }^{162}$ These limits to the scope of Charter protection must be taken into account when weighing such interests against the protection of a right as

\footnotetext{
${ }^{155}$ Charter, supra note 15, ss 2(b), 2(c).

${ }^{156}$ Peter W Hogg, "Constitutional Law of Canada" 2015 Student ed (Toronto: Thompson Reuters, 2015) at 38-26 [Hogg, 2015].

${ }^{157}$ Nicole E Negowetti, "Opening the Barnyard Door: Transparency and the Resurgence of Ag-Gag \& Veggie Libel Laws" (2015) 38:4 Seattle UL Rev 1345 at 1378.

${ }^{158}$ Note that there is no Hansard available for the regulations.

${ }^{159}$ See e.g. Ontario Hansard (18 February 2019), supra note 126 at 6944; Paul Brockman \& Yiuman Tse, "Information shares in Canadian agricultural cash and futures markets" (1995) 2:10 Applied Economics Letters 335 at 355 (describing Canada as one of the largest agriculture-producers in the world).

${ }^{160}$ See Martha Jackman \& Bruce Porter, "Socio-Economic Rights Under the Canadian Charter" (2007) Canadian Issues 26; Irwin Toy, supra note 67 (finding that "corporate-commercial economic rights" are not protected by the Charter at 1003-4); Gosselin v. Québec (Attorney General), 2002 SCC 84.

${ }^{161}$ See Reference Re Public Service Employees Relations Act, [1987] 1 SCR 313, 38 DLR (4th) 161.

${ }^{162}$ See Peter Hogg, Constitutional Law of Canada, $2^{\text {nd }}$ ed (Toronto: Carswell, 1985) at 745-56; Philip W. Augustine, "Protection of the Right to Property under the Canadian Charter of Rights and Freedoms" (1986) 18:1 Ottawa L Rev 55 at 67.
} 
fundamental as freedom of expression. Indeed, Justice L'Heureux-Dubé, dissenting in Dunmore v Ontario $(A G)$, rejected the invitation to find that "a policy geared to enhance the economic wellbeing of private enterprises" was sufficiently important to meet the first step of the Oakes test. ${ }^{163}$ In the same decision, however, the majority reasoned that "the protection of the family farm is a pressing enough objective to warrant the infringement of s. 2(d) of the Charter." ${ }^{164}$ More generally, the fact that "agriculture occupies a volatile and highly competitive part of the private sector economy [and] that it experiences disproportionately thin profit margins" made its protection a pressing and substantial reason to limit Charter rights. ${ }^{165}$ This approach aligns with the historic privileging of industrial agriculture, insofar as it garners exceptional treatment in the form of regulatory carve-outs where things like worker and animal protections are concerned. ${ }^{166}$

Still, it is worth highlighting that decisions from the Supreme Court of Canada validating the economic interests of private actors, or industry, as a pressing and substantial legislative objective are sparse, and seemingly limited to the labour context where associational rights under section 2(d) might conflict with the economic interests of private employers. Whether those interests should in fact constitute a justifiable reason to limit rights remains unsettled, with some authors suggesting they should not. Steven Barrett and Benjamin Oliphant write that "courts should be wary of succumbing to the temptation to justify limitations on strike action on the basis of economic harm or inconvenience." 167 And, beyond the labour context, "[while] the protection of the rights or freedoms of third parties may in some circumstances constitute a pressing and substantial objective for the limitation on the exercise of Charter rights or freedoms, we would

\footnotetext{
163 Dunmore, supra note 31 at para 181.

164 Ibid at para 52.

165 Ibid at para 53.

166 See Eisen, supra note 29.

${ }^{167}$ See Steven Barrett \& Benjamin Oliphant, "The Trilogy Strikes Back: Reconsidering Constitutional Protection for the Freedom to Strike" (2013) 45:2 Ottawa L Rev 201 at 228 [references omitted].
} 
propose that mere inconvenience or economic disruption rarely will." 168 Moreover, in Dunmore, while it acknowledged the erosion of "family farms" as typical of Ontario agriculture, the majority's reasoning on section 1 applied to these smaller farms and their "unique and noncommercial way of life," and not to "corporate farming and agribusiness."169

Today, large, corporate agri-business is quickly replacing the traditional family farm in Canada with so-called "intensive livestock operations," 170 similar to the well-known, and problematic, "concentrated animal feedlot operations," or CAFOs, in the United States. ${ }^{171}$ In recent years, researchers documented the "increasing concentration of power and resources in the hands of agribusiness firms and financial interests [and] the marginalization of small farmers" as two of the "dominant trends in the corporate food regime in Canada." 172 And, almost two decades ago, others observed that the North American "livestock industry, particularly the swine industry, has undergone dramatic concentration in the last twenty years." ${ }^{\prime 73}$ It seems clear that the bucolic family farm envisioned by the Supreme Court is becoming a relic of the past; it is not what legislators seem to want to protect in the guise of ag-gag legislation. The major economic interests that motivate Canadian ag-gag legislation, the apparent distinction between family farms and industrial agribusiness, and the uncertainty around the pressing and substantial nature of economic interests

\footnotetext{
168 Ibid at 229.

${ }^{169}$ Dunmore, supra note 31 ("Ontario is moving increasingly towards corporate farming and agribusiness" at para 52).

${ }^{170}$ See Heather McLeod-Kilmurray, "Commoditizing Nonhuman Animals and Their Consumers: Industrial Livestock Production, Animal Welfare, and Ecological Justice” (2012) 37:1 Bull Science, Technology \& Society 71 [McLeod-Kilmurray, "Commoditizing”].

${ }^{171}$ See Aurora Moses \& Paige Tomaselli, "Industrial Animal Agriculture in the United States: Concentrated Animal Feeding Operations (CAFOs)" in Gabriela Steier \& Kiran K Patel, eds, International Farm Animal, Wildlife and Food Safety Law (Switzerland: Springer, 2017) 185 (documenting the "horrific institutionalized abuses" of animals on industrial farms as well as the "public health endangerment and environmental degradation" caused by CAFOs at 185).

${ }^{172}$ Annette Aurélie Desmarais et al, "Land grabbing and land concentration: Mapping changing patterns of farmland ownership in three rural municipalities in Saskatchewan, Canada" (2015) 2:1 Can Food Studies 16 at 17.

${ }^{173}$ Jerry Speir et al, "Comparative Standards for Intensive Livestock Operations in Canada, Mexico, and the United States" (Technical report prepared for the Commission on Environmental Cooperation, delivered to Economics Faculty Publications and Presentations, Portland State University, 4 February 2003) at xv.
} 
as a general matter should in fact lead a court to reason differently than in Dunmore, on the question of pressing and substantial objective.

Nevertheless, the rarity with which laws are struck down based on the absence of a valid objective, combined with the high level of deference granted to governments at this first stage of the Oakes test, mean that the legislation would likely pass this step. It is therefore important to be clear about what objective exactly will ground the remainder of the analysis. The preceding paragraphs set out the legislative objectives of ag-gag legislation generally. But the section 1 test asks courts to evaluate specific rights-infringing provisions, where that is the case. ${ }^{174}$ The focus here, then, should be on the limits to expression inherent in the prohibitions on entry under false pretences, which purportedly aim to prevent the introduction of biosecurity hazards by trespassers and to protect private property and farmer safety. For their part, the prohibitions on interfering with animals in transport seek to prevent the introduction of contaminants in the food supply. The latter prohibitions, which amount to banning public protests, also aim to protect the industry more broadly. Assuming that protecting farmers, the agriculture industry, and the safety of the food system are in fact pressing and substantial objectives, the next question is whether the limits to section 2(b) are rationally connected to these objectives.

\section{The Legislation is Not Rationally Connected to the Legislative Objective}

The requirement for a rational connection between the offending measure and the legislative objective forms the first part of the proportionality stage of the Oakes test. The question here is whether "the restrictive measure is effective in advancing its pressing and substantial purpose." 175 As the Court described the question in Oakes itself, the impugned measure "must be carefully designed to achieve the objective in question. [It] must not be arbitrary, unfair or based

\footnotetext{
${ }^{174}$ See Alberta v Hutterian Brethren of Wilson Colony, 2009 SCC 37 at paras 39-40 [Hutterian Brethren].

${ }^{175}$ Moon, "Limits", supra note 70 at 50.
} 
on irrational considerations." ${ }^{176}$ As with the requirement for a pressing and substantial objective, few laws have been invalidated based on the absence of a rational connection. ${ }^{177}$ But, as Hogg observed, it does happen. ${ }^{178}$ In Ford $v$ Quebec $(A G),{ }^{179}$ " [the] Court held that while the evidentiary record was sufficient to demonstrate the importance of the government's objective [the survival of the French language], there was a complete absence of evidence on the critical question of whether 'the requirement of the use of French only is either necessary for the achievement of the legislative objective or proportionate to it." 180 The remainder of this part suggests that where Canadian aggag legislation is concerned, there is likewise little evidence that the limits on expression are rationally connected to the legislative objectives identified above, or at least to those likely to be accepted as valid by a court.

As seen, there are several objectives being pursued by different parts of the legislation. The prohibitions on entry onto a property or biosecurity area (in Alberta) and an agricultural facility (in Ontario) aim to prevent the introduction of biosecurity hazards into the food system by trespassers and to protect private property and farmer safety. The difficulty here is that trespassers, as a general matter, do not typically enter properties on false pretences. Rather, they simply enter with no prior authorization, as per both the ordinary and legal meanings of trespass. ${ }^{181}$ Indeed, as

\footnotetext{
176 Oakes, supra note 18 at 139.

177 See Hogg, 2015, supra note 156 at 38-34.1.

${ }^{178}$ See Ibid. The legislation under review in Oakes itself failed to meet the rational connection requirement; See also Greater Vancouver Transportation Authority v. Canadian Federation of Students - British Columbia Component, 2009 SCC 31; Saskatchewan (Human Rights Commission) v. Whatcott, 2013 SCC 11. or property without permission"; Irwin Law Canadian Online Legal Dictionary, (Toronto: Ontario, 2020), sub verbo "trespass" "to enter onto the lands of another, actionable without proof of injury" or "a term deriving from the ancient writ of trespass that provided a civil remedy for direct damage to person and property" and sub verbo "trespass $a b$ initio" "A principle that deems a person who enters land as of right to be a trespasser from the moment of entry if they abuse or exceed their licence while on the property." Pursuant to the latter definition, general trespass legislation may create a similar limit to speech by punishing entry onto a property where an individual "[abuses] or [exceeds] their license", in other words, abuses their permission to enter. The difference between this kind of limit on speech, and that inherent in ag-gag legislation, is the targeted nature of the ag-gag restriction and the
} 
highlighted above in one activist's testimony to the Ontario legislative committee studying Bill $156,{ }^{182}$ animal rights activists trespassing onto farms typically go out of their way to avoid encountering other people, in effect depriving themselves of the opportunity to claim they are entering on any pretence other than their activism. There is no connection, in other words, between the rights limitation - the prohibition on telling a lie in order to gain entry - and the stated objectives.

Thus, the limit on expression seems to be aimed at something else altogether - a situation where an individual, such as an investigative journalist or an animal rights advocate posing as an employee, ${ }^{183}$ may lie to gain entry onto a farm in order to document repeated animal abuses and disseminate their findings. Indeed, such undercover investigations have been at the root of some of the biggest, and most damaging, exposés of animal cruelty on industrial farms, ${ }^{184}$ and the adoption of ag-gag legislation is often a response to this kind of damaging publicity. In Idaho, for example, ag-gag legislation was a direct response to an undercover investigation by Mercy For

\footnotetext{
fact that the legislation contains a content-based restriction - that is, has the clear purpose of restricting a particular message - and accordingly constitutes a clear prima facie infringement of section 2(b). See Irwin Toy, supra note 67 ("If the government's purpose is to restrict the content of expression by singling out particular meanings that are not to be conveyed, it necessarily limits the guarantee of free expression" at 974). In any event, as explained, the Charter-infringing effect of the prohibition on entry on false pretences is not geared at, so-called, petty trespassers, but rather, at those who seek to gain regular entry to document ongoing and consistent cruel farming practices. ${ }^{182}$ Hansard (8 June 2020), supra note 142 at G-625, G-626.

${ }^{183}$ Recall that journalists are exempted from the false pretences provision in Ontario, but not in Alberta. See Bill 27, supra note 1. Even in Ontario, it's worth highlighting that journalists do not typically enter farms of their own accord, but rather, receive footage obtained through undercover tactics by animal rights organizations and advocates. See e.g. Chad Derrick, CTV WG Paragon Farms Investigation, "Undercover footage from Ontario pig farm shows alleged abuse but new laws may ban future probes" (28 November 2020), online (video): CTV News <ctvnews.ca/w5/undercover-footage-from-ontario-pig-farm-shows-alleged-abuse-but-new-laws-may-ban-futureprobes-1.5207579> (footage collected by Animal Justice and turned over to CTV); Mercy For Animals, "'Horrific' abuse of cows at BC Dairy farm caught on video" (9 June 2014), online (video): CTV News $<$ ctvnews.ca/canada/horrific-abuse-of-cows-at-b-c-dairy-farm-caught-on-video1.1860892? cache=mqtvfodkrwpz\%3FclipId\%3D89578> (footage collected by Mercy For Animals and turned over to CTV). This practice demonstrates the difficulties with drawing boundaries between so-called traditional journalism, whistleblowing, and advocacy, as well as the necessary connections between them.

${ }^{184}$ See Chen \& Marceau, "High Value Lies", supra note 72 at 1466 (for American examples); Postmedia News, "Undercover investigation reveals horrific cruelty at B.C. dairy farm, SPCA recommending charges" (10 June 2014), online: National Post < nationalpost.com/news/canada/undercover-investigation-reveals-horrific-cruelty-at-bc-dairy-farm-spca-recommending-charges> (for a Canadian example).
} 
Animals, which revealed horrific cruelty on a dairy farm. ${ }^{185}$ That law has since been struck down as a breach of the First Amendment protection of freedom of speech. ${ }^{186}$ The issue, at the level of rational connection, then, is the "complete absence of evidence" that these types of activities constitute a threat to biosecurity or farmer safety. ${ }^{187}$ This absence of connection was precisely what motivated another American court to strike down similar legislation. Judge Gritzner, of the US District Court, Southern District of Iowa, reasoned: "Defendants have produced no evidence that the prohibitions [on entry under false pretences] are actually necessary to protect perceived harms to property and biosecurity.... Defendants have made no record as to how biosecurity is threatened by a person making a false statement to get access to, or employment in, an agricultural production facility." ${ }^{188}$ The idea, of course, is that an animal rights activist who obtains employment in order to document farm practices will be trained, like any other employee, and expected to adhere to biosecurity protocols. ${ }^{189}$ Trespassers are distinct from those who enter on false pretences, and while they may or may not introduce contaminants onto farms-although there is little evidence that they do- that is irrelevant to the relationship between prohibiting entry on false pretences and the stated legislative objectives, which seem to have no connection at all.

Similarly, there is little evidence of any relationship between the prohibitions on interacting with animals in transport and the stated objective of protecting the food supply. As discussed above with respect to the pressing nature of the goal of protecting food safety, the legal system has previously rejected, based on an absence of evidence, the suggestion that members of the Animal Save Movement, who protest on public roads and bear witness to the suffering of animals as they

\footnotetext{
185 See Marceau, supra note 11.

${ }^{186}$ See Wasden, supra note 14.

${ }^{187}$ Choudhry, supra note 83 at 526.

${ }^{188}$ Reynolds, supra note 14 at 15.

${ }^{189}$ Herbert, supra note 14 at paras 40-43; Ibid, at para 49.
} 
are trucked off to slaughter, pose any biosecurity hazards to the animals that they attempt to comfort and, in turn, to the food system. ${ }^{190}$ In $R v$ Krajnc, Anita Krajnc, the founder of the Animal Save Movement, was charged with the crime of mischief when she gave water to pigs on a transport truck on a hot summer day, as she and fellow protestors regularly did. ${ }^{191}$ At trial, the Crown suggested that Ms. Krajnc "gave 'an unknown substance / possible contaminant' to the pigs thereby creating a risk that the slaughterhouse would refuse to take them." 192 The judge rejected this theory, based on an absence of evidence that either the truck driver or the slaughterhouse showed any actual concern about a possible contaminant:

[71] Crown counsel argued that Ms. Krajnc created a risk that the slaughterhouse would refuse the load on the basis that they might be contaminated. The farmer and the truck driver both testified that this possibility caused them very real concern.

[72] Again I find that this is completely contradicted by the evidence.

[73] Protesters had given water to pigs before. The driver was aware of this. The slaughterhouse was aware of this. Despite this, the slaughterhouse had never refused to accept a load of pigs for that reason.

[74] As I stated above they did not reject that particular load on that particular day. ${ }^{193}$

A finding by one trial judge is not a conclusive statement on the evidentiary basis for Canadian ag-gag legislation. But it is telling that the only judicial pronouncement on the relationship between slaughterhouse protests and the risk of contaminating the food supply involves a categorical rejection of the purported connection. Justice Harris's reasoning in $R v$ Krajnc seriously undermines the existence of the rational connection required of constitutionally justifiable rights infringements.

\footnotetext{
${ }^{190}$ See Krajnc, supra note 56.

191 See ibid.

192 Ibid at para 58.

${ }^{193}$ Ibid at paras 66-74 [emphasis in original].
} 
As discussed, all of the offending provisions, and ag-gag legislation generally, are related to the broader objective of protecting and supporting the agriculture industry. Assuming that protecting the economic interests of private actors constitutes a pressing and substantial reason to limit fundamental rights, which remains unclear, this objective poses further problems at the level of rational connection. As suggested in the legislative debates, ${ }^{194}$ by MPPs studying Bill 156 at committee, ${ }^{195}$ and by research out of the United States and Canada, ${ }^{196}$ ag-gag legislation may do more harm than good to the reputation of industrial animal agriculture. Rather than protecting the industry, the removal of transparency inherent in ag-gag legislation, which shields the industry from public scrutiny, has been shown to erode public trust in farmers and to increase support for animal welfare. ${ }^{197}$ Paradoxically, then, by undermining public confidence in animal agriculture, ag-gag legislation achieves the exact opposite of the legislative objective-instead of protecting, it risks harming the industry and the economic interests of farmers. In other words, it is entirely ineffective in advancing its purpose and accordingly does not meet the requirement that rightslimiting legislation be rationally connected to its objective.

\section{The Legislation is Not Minimally Impairing}

The test for minimal impairment, the second stage of proportionality, has been restated a number of times in the years since Oakes. In 2015, Hogg described it as the "requirement of least drastic means. ... The idea is that the law should impair the right no more than is necessary to

\footnotetext{
194 See Ontario Hansard (20 February 2019), supra note 134 at 7026.

195 Hansard (8 June 2020), supra note 142 at G-600.

196 See JA Robbins, DM Weary \& MAG von Keyserlingk, “'Ag-Gag laws' increase negative perceptions of farm animal welfare and decrease trust in farmer" in Know Your Food: Food Ethics and Innovation (Wageningen, the Netherlands: Wageningen Academic Publishers, 2015) 297; JA Robbins et al, "Awareness of ag-gag laws erodes trust in farmers and increases support for animal welfare regulations" (2016) 61 Food Policy 121.

${ }^{197}$ See Ontario Hansard (20 February 2019), supra 134 ("A 2016 study from the UBC found that when the public learns of so-called ag gag laws, it erodes trust in the farmers and increases support for animal welfare regulations" at 7026).
} 
accomplish the desired objective...." ${ }^{198}$ In practice, however, courts do not typically look for the "least intrusive" measure, but rather, seek to ensure that the "challenged measure ... only [impairs] Charter rights as little as is reasonably possible and [ask] whether there is some reasonable alternative scheme." 199 Given that courts regularly defer to governments balancing different interests, the question here is often "whether it could be said that the government had a 'reasonable basis' for concluding that that it had impaired the right as little as possible." ${ }^{200}$ That said, as highlighted above, where the speech being limited is political in nature, the degree of deference afforded by the court will be low. ${ }^{201}$ Importantly, given the rarity with which laws fail at the previous two steps, minimal impairment "has turned out to be the heart and soul of s. 1 justification. ${ }^{" 202}$ Moreover, as with the other parts of the Oakes test, the evidence is paramount in determining whether the limits are among a range of reasonable options for the government to meet its desired objectives. The following paragraphs suggest that ag-gag legislation does not meet this standard and accordingly fails the minimal impairment test.

There are reasonable alternatives, with lesser impacts on rights, that would achieve the objectives of protecting biosecurity, farmer safety, and the overall integrity of the food system. In fact, it is possible to achieve each of these objectives without limiting freedom of expression at all, especially given the tenuous connection, demonstrated above, between the restriction on speech and the objectives. The legislation, in both Alberta and Ontario, increases existing penalties for trespassing onto private property or an agricultural facility, respectively, and prohibits entry on false pretences by deeming it a trespass. The penalties (fines and/or jail in Alberta and fines in

\footnotetext{
${ }^{198}$ Hogg, 2015, supra note 156 at 38-36.

${ }^{199}$ Choudhry, supra note 83 at 507 [references omitted].

${ }^{200} \mathrm{Ibid}$ at 511, citing Irwin Toy, supra note 67 at 994.

${ }^{201}$ See Choudhry, supra note 83 at 515.

${ }^{202}$ Hogg, 2015, supra note 156 at 38-36.
} 
Ontario), and the legislation more generally, are meant to dissuade activists from trespassing onto farms and occupying animal enclosures, in order to achieve the broader objectives. ${ }^{203}$ As set out already, however, it is not clear how the prohibition on entry under false pretences relates to these objectives. It stands to reason, then, that these objectives can be achieved without limiting expression. Indeed, the most efficient way to dissuade trespassing in order to promote biosecurity and farmer safety seems to be by prohibiting trespassing. And while it is not for courts to impose what they view as the best solution to a particular policy problem, ${ }^{204}$ it is incumbent on them to hold governments to account when legislation limits rights unnecessarily. Here, prohibiting trespass alone, without restricting expression, would achieve the legislative goal, and would limit freedom of expression less than the false pretences provisions. Accordingly, these provisions limit rights more than necessary, and thus fail the minimal impairment test.

The protection of biosecurity can also be achieved through less impairing measures that do not limit high-value speech. For example, at the federal level, Bill C-205, ${ }^{205}$ which died on the order table when the 2021 election was called, would have amended the federal Health of Animals Act so as to prohibit the introduction of a "disease or toxic substance" into a place where animals are kept. ${ }^{206}$ In other words, the amended legislation would protect against biosecurity threats by limiting exposure to contaminants and not by limiting speech. Surely, this bill demonstrates the

\footnotetext{
${ }^{203}$ See Alberta Hansard (25 November 2019), supra 116 at 2524; Ontario Hansard (10 December 2019), supra note 122 at 6801.

${ }^{204}$ See $R J R$-MacDonald, supra note 88 ("If the law falls within a range of reasonable alternatives, the courts will not find it overbroad merely because they can conceive of an alternative which might better tailor objective to infringement" at para 160); Hutterian Brethren, supra note 174 at para 54.

${ }^{205}$ Bill C-205, An Act to amend the Health of Animals Act, 1st Sess, 43rd Parl, 2020.

${ }^{206} \mathrm{Ibid}$, s 1 . Interestingly, Bill C-205 was originally aimed only at people without lawful authority to be on a farm, i.e. trespassers, and only prohibited the introduction by that category of individuals. At Second Reading, the Bill was amended by the Standing Committee on Agricultural and Agri-Food to apply to any individual who introduces a risk of disease to animals, in recognition of evidence that trespassers (i.e. animal rights activists) have never been responsible for a disease outbreak and that outbreaks are far more likely to result from industry practices. See House of Commons, Standing Committee on Agriculture and Agri-Food, 43-2, No 40 (17 June 2021). (Again, in the interests of transparency, I participated in this process as well.)
} 
existence of alternative means of achieving the principal legislative objective of ag-gag legislation that are less harmful to fundamental freedoms. ${ }^{207}$

It is tempting to view the exceptions for journalists and employee whistleblowers in Ontario's regulation as a means of narrowing the restriction on expression so that the law only impairs rights minimally. ${ }^{208}$ Recall that where an employee of an animal use facility gained entry to that facility based on false pretences, they are not deemed to have trespassed, provided they document harm to an animal and immediately turn it over to authorities. ${ }^{209}$ As explained, this obligation, or quick report requirement, by preventing the documentation of systemic and repeated patterns of abuse, undermines the reason for going undercover on a farm. As for journalists, they are only exempt where they do not cause harm to an animal, to food safety, or to an individual. ${ }^{210}$ But the term "harm to an individual" is defined as "emotional or psychological injury, including undue stress." ${ }^{211}$ It is difficult to imagine the negative press that results from an exposé disclosing animal mistreatment not causing some kind of psychological injury or stress to the individuals involved. Further, the regular work of industrial animal agriculture necessarily harms—and, where meat is concerned, kills - animals. Thus, the exceptions, limited as they are, do little to minimize the rights infringements inherent in Ontario's law.

Finally, Ontario's legislation is extremely broad in application. The regulation defines farm animal, with whom individuals are prohibited from interacting, ${ }^{212}$ as animals bred for a number of purposes including "to propel vehicles" (i.e. carriage horses), "to be ridden for pleasure" (i.e.

\footnotetext{
${ }^{207}$ This is not an endorsement of the policy rationale for Bill C-205, which, based on the relevant debates and the Bill's original form, was clearly aimed at restricting animal rights activism. It is merely an example of a less impairing way of achieving a similar objective.

${ }^{208}$ See Reg 701/20, supra note 57, ss 11, 12.

${ }^{209} \mathrm{Ibid}, \mathrm{s} 12$.

${ }^{210} \mathrm{Ibid}, \mathrm{s} 11$.

${ }^{211} \mathrm{Ibid}, \mathrm{s} 1$.

${ }^{212}$ Security from Trespass Act, supra note 3, ss 5(4), 6(1), 6(2).
} 
horses ridden recreationally), "to be shown publicly..." (for example, at a petting zoo), and "to undertake competitions" (i.e. race horses). ${ }^{213}$ None of these activities form part of the food system. In characterizing the places these kinds of animals are kept as those where trespassing risks compromising biosecurity and food safety, the legislation overreaches, or impairs rights more than is necessary. A law genuinely aimed at protecting farmer safety and the food system would stop at the borders of personal property and food production and would limit speech only as much as necessary to achieve those objectives. The real possibility of less impairing measures thus makes clear that both Ontario's and Alberta's legislation fails the minimal impairment stage of the Oakes test. This failure, either alone or in conjunction with the absence of a rational connection, is enough for a court to declare the legislation of no force or effect. But in the interests of being comprehensive, the following part will briefly weigh the effects of the legislation.

\section{The Legislation is Not Proportionate in its Effects}

The final stage of the Oakes test asks "whether the Charter infringement is too high a price to pay for the benefit of the law." ${ }^{214}$ Here, the positive and negative impacts of an impugned measure are weighed, and the requirement of proportionality is met when the positive effects outweigh the negative. While courts have varied in their emphasis on this part of the analysis, and some scholars have questioned its utility, ${ }^{215}$ a majority of the Supreme Court has emphasized its importance. In Hutterian Brethren, Chief Justice McLachlin not only confirmed that the proportionality of effects test is integral to section 1, but also clarified the rationale of the analysis, as well as the meaning of the salutary and deleterious effects to be balanced. Accordingly, whereas the earlier stages of the Oakes test-pressing and substantial objective, rational connection, and

\footnotetext{
${ }^{213} \operatorname{Reg} 701 / 20$, supra note 57, s 5.

${ }^{214}$ Hogg, 2015, supra note 156 at 38-43.

215 See ibid at 38-44 for the idea that this part of the test is unnecessary and "redundant".
} 
minimal impairment — "are anchored in an assessment of the law's purpose," 216 the fourth stage takes full account of the "severity of the deleterious effects of a measure on individuals or groups." ${ }^{217}$ In other words, as it examines the impacts of legislation on their own, and not in connection with the legislative objective, the proportionality of effects test involves a more subjective assessment than the preceding inquiries.

Salutary effects are straightforward; they are the beneficial effects of the legislation in question. As Hogg suggested, they will typically align with the legislative objective, already accepted as pressing and substantial. ${ }^{218}$ With respect to Canadian ag-gag laws, then, the benefits would, assuming these objectives were accepted by a court, align with the goals of protecting the safety of farmers and their property and guarding against the introduction of biosecurity threats to the food system by trespassers and activists outside of slaughterhouses.

Deleterious effects are less clear cut and, as with much analysis under the Charter, vary according to the case and the seriousness of the limit in question. Referring to a restriction on religious freedom, Chief Justice McLachlin wrote, "[there] is no magic barometer to measure the seriousness of a particular limit..." and that seriousness will depend on the nature of the practice. ${ }^{219}$ The same, of course, might be said about freedom of expression, with the effect that limits to political speech - that is, the type of expression limited by ag-gag laws — should be viewed as particularly severe. Indeed, where constitutional protections are concerned, "no lie is more valuable than the lie that enables important speech on issues of public concern." 220 The negative effects of Canadian ag-gag laws, in other words, are considerable.

\footnotetext{
${ }^{216}$ Hutterian Brethren, supra note 174 at para 76.

${ }^{217}$ Ibid [references omitted].

${ }^{218}$ Hogg, 2015, supra note 156 at 38-44.

${ }^{219}$ Hutterian Brethren, supra note 174 at para 89.

${ }^{220}$ Chen \& Marceau, "High Value Lies", supra note 72 at 1507.
} 
Chief Justice McLachlin further suggested that the evaluation of a law's deleterious effects will depend on its impacts "in terms of Charter values, such as liberty, human dignity, equality, autonomy, and the enhancement of democracy." 221 As seen, ag-gag laws constitute a restriction on political speech — that is, speech meant to enhance democracy. Moreover, for many animal rights activists, their commitment to their cause may be comparable to religious or conscientious beliefs, ${ }^{222}$ such that limits on their ability to manifest their beliefs through activism constitute an affront to their liberty and dignity. Where ag-gag laws are in force, animal rights activists have a choice between getting their message out and facing possible penalties, on the one hand, or remaining silent in the face of the unspeakable violence animals experience on industrial farms, in transport, and in slaughter, on the other. ${ }^{223}$ This is not a "meaningful choice." 224 Instead, as Justice LeBel reasoned, dissenting in Hutterian Brethren, "when significant sacrifices have to be made to [exercise constitutional freedoms] in the face of a state imposed burden, the choice to [do so] is no longer uncoerced." 225 Add to this the idea that undercover investigations and slaughterhouse protests are some of the only ways to bring to light the suffering of farmed animals, and the weight of the negative impacts of ag-gag legislation becomes very clear. Proportionality of effects is a

\footnotetext{
${ }^{221}$ Hutterian Brethren, supra note 174 at para 88.

${ }^{222}$ See Harold A Herzog, Jr, “The Movement is My Life': The Psychology of Animal Rights Activism” (1993) 49:1 J Soc Iss 103; Donna D Page, "Veganism and Sincerely Held Religious Beliefs in the Workplace: No Protection without Definition" (2005) 7:2 U Pa J Lab \& Employment L 363; Bruce Friedrich, "The Church of Animal Liberation: Animal Rights as Religion under the Free Exercise Clause" (2014) 21:1 Animal L 65. Contra Jan Dutkiewicz \& Jonathan Dickstein, "The Ism in Veganism: The Case for a Minimal Practice-based Definition" (2021) 6:1 Food Ethics 1. There is a need for further research on the connection between freedom of conscience and religion as interpreted in Canada and animal rights activism, and the related question of whether Canadian ag-gag laws constitute a restriction on the s 2(a) Charter guarantee of freedom of conscience, as something distinct from religious freedom. For present purposes, however, there is literature suggesting that limits on the right to participate in animal rights activism and to express one's ethical and political commitments regarding animals do impact the liberty and dignity of those who espouse these commitments.

${ }^{223}$ On the appropriateness of using the word "violence" to describe the regular practices of industrial farming see Gillespie, \#1389, supra note 27 at 21 (describing how "violence against certain lives and bodies can become so normalized that it is not viewed as violence at all).

${ }^{224}$ See Hutterian Brethren, supra note 174 at para 163, LeBel J, dissenting.

${ }^{225} \mathrm{Ibid}$ at para 167.
} 
subjective inquiry. But surely, the absence of a meaningful choice, combined with restrictions on political speech and the related impacts on activists' liberty and dignity, outweigh any salutary effects of Canadian ag-gag legislation.

\section{Conclusion}

This article completes the argument that Canadian ag-gag legislation, recently adopted in a number of Canadian jurisdictions, constitutes a restriction on the constitutional right to freedom of expression that cannot be justified under section 1 of the Charter. After reviewing the ways that prohibitions on entry under false pretences and interference with motor vehicles transporting farmed animals limit high-value political speech — the kind of speech that lies at the heart of the guarantee — the article sets out the challenges that governments might face in attempting to justify the restrictions under the section 1 Oakes test. This is not a novel story, but one that has already played out south of the border. American ag-gag legislation dates to the early 1990s and has taken many forms - from rarely used food libel laws, also known as "agricultural disparagement statutes," to prohibitions on non-consensual recording on farms, to prohibitions on entry under false pretences, ${ }^{226}$ similar to those that I have scrutinized here. Indeed, where ag-gag laws are concerned, legislators seem influenced by cross-border policies in both directions. Where Canadian trespass laws originated in the US, the transport related provisions in Alberta, Ontario, and Manitoba have now been exported to Iowa as well. ${ }^{227}$

As discussed above, and elsewhere, ${ }^{228}$ all of these laws, in both Canada and the United States, were drafted in response to the activities of undercover journalists, whistleblowers, and animal rights activists who have made visible what the corporate animal agriculture industry

\footnotetext{
${ }^{226}$ See Marceau, supra note 11.

${ }^{227}$ See US, HFF 655, A Bill for an Act Prohibiting Interference with the Transportation of an Agricultural Animal, and Providing Penalties, 89th General Assembly, Reg Sess, Iowa, 2021 (enacted).

${ }^{228}$ See Lazare, supra note 7.
} 
wishes to hide. ${ }^{229}$ Moreover, in the United States, as seen, many of these statutes - particularly those that mirror the ones at issue here-have been ruled unconstitutional for their interference with the First Amendment right to free speech. Canadian ag-gag legislation, then, raises the same contest of values between the goal of protecting a billion-dollar industry through secrecy and concealment, on the one hand, and the pursuit of truth and information about important subjects of public debate, on the other. While the legal approach may differ in Canada, given the that courts tend to tolerate greater intrusions on free expression, ${ }^{230}$ my analysis suggests that the same interests that prevailed in the United States should triumph here as well. Indeed, information about how animals in the food system are treated is no less important to the Canadian public than to Americans, and, as seen, the evidence connecting ag-gag legislation and its purported objectives is equally weak on both sides of the border.

While protecting both the safety of farmers and the food system may be valid legislative objectives, there is little evidence that these things are threatened by the kinds of animal activism the legislation aims to prevent. Moreover, it is an open question whether protecting the economic interests of industrial agriculture constitutes a pressing and substantial objective in line with the Charter jurisprudence; there are compelling reasons that the economic protection of a billiondollar industry should not be permitted to trump the individual rights and freedoms guaranteed by the Constitution, particularly when the rights in question are fundamental to citizen engagement with and participation in democratic and political processes. At the level of rational connection, neither the history nor the evidence supports the relationship between the prohibited expressionentry onto farms and bearing witness on public roads - and the mischief being targeted; activists

\footnotetext{
${ }^{229}$ See Marceau, supra note 11.

${ }^{230}$ See e.g. Léonid Sirota, "Compelled Speech: A Conscience- and Integrity-Based Approach" in MacFarlane, supra note 80, 151 ("To be sure, [the Supreme Court of the United States] is generally more solicitous of the freedom of expression than Canadian courts are" at 156).
} 
take steps to avoid harming both humans and nonhuman animals. The legislation is also not minimally impairing; there are ways of achieving the stated objectives that do less harm to Charter freedoms. In terms of proportionality of effects, the final stage of the section 1 analysis, legislators behind Canadian ag-gag legislation have a difficult case to make. Ag-gag laws impact Charter values in serious ways. For some activists who have made an ethical commitment to call out and combat the incredible cruelty of industrial animal farming, the laws preclude a meaningful choice between activists carrying out their conscientious beliefs and being charged and potentially imprisoned (in Alberta) or fined. That absence of individual choice affects the dignity and autonomy of people committed to challenging and changing the ways that we, as a society, relate to nonhuman animals. These kinds of deleterious impacts will not be easily outweighed by the purported objectives of Canadian ag-gag legislation.

Analyzing rights infringements using the section 1 Oakes framework has become a routine part of constitutional adjudication and decision-making in Canada. But section 1 justification was not always understood as a habitual or standard practice. Indeed, drafters of the Charter "envisaged section 1 as a way of occasionally preserving the abilities of legislatures to determine the primacy of particular values or policies...."231 As Kent Roach has written, section 1 enables courts to examine "adverse effects of laws in exceptional cases."232 It does not empower governments to trample on the civil liberties guaranteed by the Charter in order to immunize from public scrutiny the hidden cruelty inherent in large-scale industrial animal farming. But in the years since its adoption in 1982, and especially since the Oakes test was set out, "the Court has become overwhelmingly deferential to governmental assertions about the importance and justification" of

\footnotetext{
${ }^{231}$ Janet L Hiebert, Limiting Rights: The Dilemma of Judicial Review (McGill-Queen's University Press: Montreal \& Kingston, 1996) at 52 [emphasis added].

${ }^{232}$ Roach, supra note 95 at 384 [emphasis added].
} 
rights-infringing legislation, ${ }^{233}$ at the level of the legislative objective, ${ }^{234}$ and throughout the remainder of the analysis. In ag-gag legislation, courts have a clear and straightforward opportunity to re-establish the constitutional limits involved in policy-making that negatively affects highvalue expression.

This article focuses on the difficulties involved in justifying Canadian ag-gag legislation's impacts on the right to freedom of expression. But ag-gag laws provide an opportunity for other constitutional inquiries and contributions to the literature on interpreting Charter protections and raise important questions about the privileged treatment of the agriculture industry in Canada. Future research will explore whether ag-gag laws also limit freedom of conscience, insofar as an ethical commitment to nonviolent and respectful relationships with nonhuman animals might qualify as a comprehensive belief system grounded in secular morality and deserving of the protection of section 2(a) of the Charter. This is a particularly timely inquiry given parallel developments in the United Kingdom and legal proceedings currently underway in Canada. ${ }^{235}$ Moreover, as stated at the outset, there is a need for further critical inquiry into Canadian agricultural exceptionalism, or the idea that, for a number of reasons, and as exemplified by aggag legislation, "regulators should treat agriculture as an exceptional sector." ${ }^{236}$ Indeed, privileged protections for the industry appear to align with the increased concentration of the agri-food industry and the rise of "Intensive Livestock Operations" in Canada, both of which merit scrutiny, given the demonstrated negative impacts of intensive animal farming on human rights, health and

\footnotetext{
${ }^{233}$ Hiebert, supra note 231 at 79.

234 Ibid.

${ }^{235}$ See Adam Knauff v Ministry of Natural Resources (29 May 2018), Human Rights Tribunal of Ontario (Application Schedule A) <canadianlawyermag.com/staticcontent/AttachedDocs/Adam\%20Knauff.pdf>; Casamitjana $v$ The League Against Cruel Sports (3 February 2020), No 3331129/2018, online: UK Employment Tribunal <gov.uk/employment-tribunal-decisions〉.

${ }^{236}$ Alford \& Berger Richardson, supra note 29 at 149.
} 
safety, nonhuman animal interests, and the climate. ${ }^{237}$ For present purposes, however, the freedom of expression and justification analyses are sufficient to raise significant red flags about both the constitutionality and the general wisdom of Canadian ag-gag legislation.

${ }^{237}$ See McLeod-Kilmurray, "Commoditizing”, supra note 170. 